\title{
TAFSIR AL-AZHAR: Suatu Tinjauan Biografis dan Metodologis
}

\author{
Malkan \\ STAIN Datokarama Palu, Jl.Diponegoro 23 Palu \\ e-mail: malkan67@yahoo.com
}

\section{Abstract}

This article deals with Tafsîr al-Azhâr from biographical and methodological perspectives employing historical method. Hamka started writing this Tafsîr al-Azhâr in 1959 than convoyed it as a down lecture in the Mosque of al-Azhâr. He completed the writing of this book of al-tafsîr when he was being jailed. This book of al-tafsîr consists of thirty chaptersl. After analyzing the contents of the book of al-tafsir , the writer found that Hamka employed rational method with literature and social patterns based on the school of Islamic orthodoxy and Islamic free act.

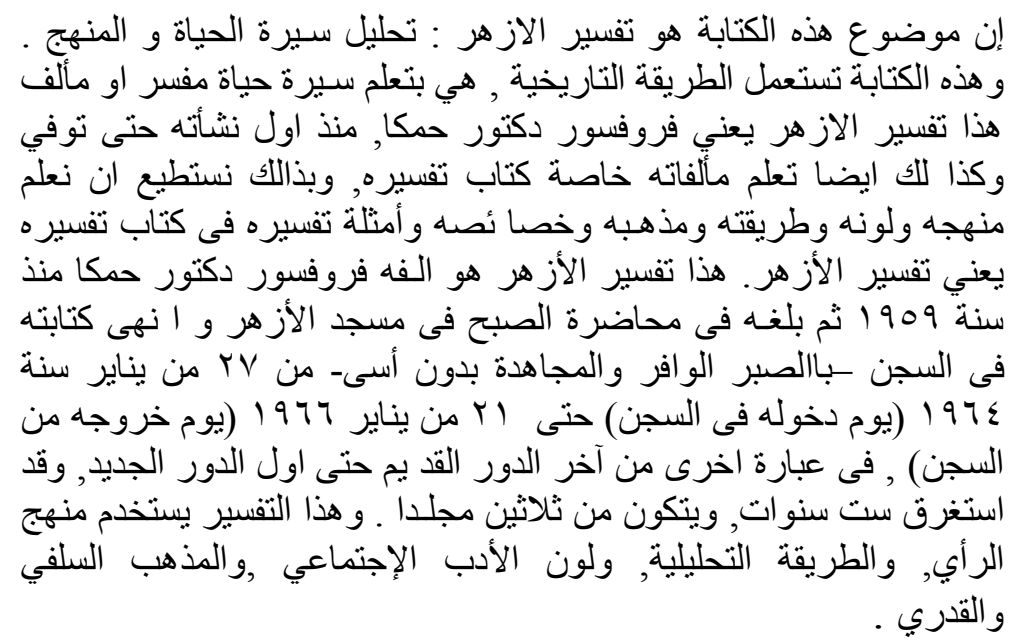

Kata Kunci: Hamka, Tafsîr al-Azhâr, tafsir bi al-ma'tsur, tafsir bi al-ra'y, metode tahlilî, corak penafsiran adabî, corak penafisran ijtimâ' $\hat{\imath}$ 


\section{PENDAHULUAN}

Alquran diturunkan tidak hanya bagi orang-orang Arab Ummiyyin yang hidup pada zaman rasul saw. dan tidak pula hanya bagi generasi abad ke-20, tetapi juga bagi semua manusia sampai akhir zaman. Oleh karena itu, semuanya diajak berdialog oleh Alquran dan diharapkan dapat memanfaatkan akal dan hati manusia dalam memahaminya (Shihab, 1992:105). Selanjutnya, agar seseorang dapat memahami Alquran dengan baik, ia harus merujuk kepada tafsir Alquran yang menjelaskan atau menerangkan firman Allah swt. dan memberikan pengertian menyangkut hal-hal yang terkandung dalam Alquran (Al-Syirbashi, 1994: 5).

Secara historis, usaha penulisan tafsir di Indonesia telah berlangsung cukup lama. Tafsir pertama yang dianggap sempurna dan didapatkan naskahnya secara lengkap adalah karya Abdurrauf Singkel, yang berjudul Tarjuman al-Mustafid, yang ditulis pada abad ke-17 M. Rentang waktu dari abad ke-17 sampai sekarang, terdapat sejumlah kitab tafsir yang telah dihasilkan oleh pakar Alquran di negeri kita, di antaranya adalah Mârah Labîd, karya Syeikh Nawâwî al-Bantânî, Tafsir Qur'an Karim karya Prof. Dr. Mahmud Yunus, Tafsir Qur'an karya H. Zainuddin Hamidi dan Fachruddin HS, Tafsir An-Nur dan Tafsir Al-Bayan karya Prof. Dr. TM. Hasbi As-Siddiqie, Tafsir Sinar karya A. Malik Ahmad, Tafsir Furqan karya A. Hassan, Tafsir AlAzhar karya monumental Prof. Dr. Hamka, dan lain-lain (Shihab, 2003: xxxiv-xxxv).

Tafsir yang akan dibahas dalam tulisan ini adalah Tafsir AlAzhar karya Prof. Dr. Hamka. Tafsir ini banyak dirujuk oleh para pengkaji Alquran karena di samping bahasanya mudah dan menyejukkan, penjelasannya juga mendetail serta mengikuti perkembangan zaman. Bahasan tulisan ini meliputi: Biografi Mufasir dan Tafsir Al- Azhar, Manhaj Tafsir, Metode Tafsir, dan Corak Tafsir.

\section{BIOGRAFI MUFASIR DAN TAFSIR AL-AZHAR}

\section{Biografi Mufasir}

Hamka (Haji Abdul Malik Karim Amrullah) lahir pada tanggal 16 Februari $1908 \mathrm{M}$ bertepatan dengan tanggal 13 Muharram $1326 \mathrm{H}$, di sebuah desa yang bernama Tanah Sirah, dalam Nagari Sungai 
Batang, terletak di tepi Sungai Maninjau. Ayahnya bernama Syekh Abdul Karim Amrullah, (Yusuf, 2003:39) yang terkenal dengan sebutan Haji Rasul adalah seorang tokoh ulama yanng cukup terkemuka dan pembaharu di Minangkabau (Tim IAIN Syahid, 1992: 294).

Hamka sewaktu kecil dipanggil Abdul Malik. Memulai pendidikannya membaca Alquran di rumah orang tuanya sendiri, yaitu pada saat mereka sekeluarga hijrah dari Maninjau ke Padangpanjang, pada tahun 1914. Setahun kemudian, ketika usiannya mencapai tujuh tahun, ayahnya memasukkannya (Hamka kecil) ke sekolah desa (Yusuf, 2003:40).

Ketika Zainuddin Labai El-Yunusi mendirikan Sekolah Diniyah sore hari, di Pasar Usang Padangpanjang pada tahun 1916, Hamka kemudian masuk di sekolah tersebut. Dengan demikian, Hamka belajar di sekolah desa pada waktu pagi hari, di Sekolah Diniyah pada sore hari dan ia berada di surau bersama dengan teman-teman seumurnya pada malam hari. Demikianlah siklus aktivitas Hamka sehari-hari dalam usia kecilnya. Siklus aktivitas tersebut sangat mengekang kebebasan masa kanak-kanaknya. Keadaan "terkekang" ini ditambah lagi dengan sikap ayahnya yang bersifat "otoriter", sebagai seorang ulama yang disegani saat itu, sehingga tidak jarang menimbulkan perilaku yang menyimpang dalam perkembangan pribadi Hamka. Oleh karena itu, ia dikenal sebagai "anak nakal". Hal ini diakui oleh A. R. Sutan Mansur, orang yang memiliki pengaruh besar dalam pertumbuhan pribadi Hamka sebagai seorang mubalig (Yusuf, 2003:40).

Ketika Hamka telah dikhitan di kampung halamannya, Maninjau, tahun 1918, ayahnya dari lawatan pertamanya ke tanah Jawa, Surau Jembatan Besi, tempat di mana Syekh memberikan pelajaran agama dengan sistem lama, diubah menjadi madrasah yang kemudian terkenal dengan nama "Thawalib School". Ini bertujuan agar Hamka kelak menjadi ulama sekaliber dia. Sejak Thawalib School, Hamka berhenti di Sekolah Desa (Yusuf, 2003: 40-41).

Pada awal perkembangannya, Thawalib School belum sanggup melepaskan diri dengan sistem lama dalam belajar agama. Walaupun unsur pembaruan telah memasuki lembaga pendidikan tersebut. Bahkan menurut Mahmud Yunus (dalam Yusuf, 2003:41), Surau Jembatan Besi yang sejak awal menyajikan materi pelajaran agama 
dengan sistem lama adalah surau yang pertama menerapkan sistem klasikal di Minangkabau. Ada terdapat tujuh kelas yang dipersiapkan oleh Thawalib School. Meskipun sistem klasikal telah diberlakukan oleh lembaga pendidikan tersebut, kurikulum dan materi pelajaran masih tetap memakai cara lama. Terbukti buku-buku lama dengan keharusan menghafal, masih merupakan ciri utama pada sekolah tersebut. Hal inilah yang menjadikan Hamka cepat bosan dan tidak betah, bahkan - dengan meminjam istilah Hamka sendiri - membuat kepalanya pusing. Kendatipun demikian, ia tetap dapat naik kelas hingga ia duduk di kelas empat.

Keadaan tersebut di ataslah yang kemudian membawa Hamka berada di perpustakaan milik Zainuddin Labai El-Yunusi dan Bagindo Sinaro. Ia keasyikan di perpustakaan ini membaca buku-buku cerita dan sejarah. Perpustakaan tersebut, yang diberi nama Zinaro, telah menyuguhkan suatu betuk kegairahan tertentu baginya. Tindihan rasa tertekan yang dialaminya selama ini memperoleh tempat pelarian di perpustakaan tersebut. Sayangnya, pertumbuhan imajinasi masa kanak-kanaknya itu sesekali menemui juga batu sandungan berupa semprotan kata-kata dari ayahnya, pada saat ia asyik membaca sebuah buku silat, yang berbunyi: "Apakah engkau akan menjadi orang alim untuk menggantikan aku atau akan menjadi tukang cerita" (Yusuf, 2003:41-42).

Peristiwa di atas dapat menggoncangkan jiwanya, kemudian disusul perceraian ayah dengan ibunya, karena merupakan keharusan menurut adat. Sungguh sangat mungkin kalau kemudian peristiwa ini membentuk sikapnya yang menganggap beberapa praktek adat tidak relevan dengan ajaran Islam. Dan adat khususnya praktik kawin-cerai, yang tak lapuk oleh hujan dan tak lekang oleh panas, dalam pandangan Hamka "misalkan batu, dan sebab batu tersebut sudah berlumut maka sudah masanya disimpan di museum". Adanya ketentuan adat dan kebolehan berpoligami dalam Islam telah terasimilasikan dalam alam pikiran Minangkabau. Asimilasi tersebut memberikan kemungkinan yang begitu luas pada para ulama, sebagai orang yang terpandang di tengah masyarakat dalam rangka memperoleh pembenaran untuk melaksanakan kawin-cerai secara berganti-ganti. Realita ini pulalah yang ditemukan Hamka terjadi pada ayahnya, Syekh Abdul Karim Amrullah. Akibatnya, Hamka menjadi 
terlantar, yang pada akhirnya menjadikan "kenakalan"-nya berubah menjadi semacam "pemberontakan" (Yusuf, 2003:42).

Realita tersebut membuatnya ingin mengisolirkan diri dari ayahnya untuk pergi ke tanah Jawa. Sayangnya, "pelarian" ini terhalang di Bengkulen, sebab ia terkena wabah cacar. Selama dua bulan ia tinggal di pembaringan. Setelah sembuh, ia kembali ke Padangpanjang dengan wajah yang penuh bekas cacar. Kegagalan ini tidak menjadikan Hamka putus asa. Setahun kemudian (1924), ia pun berangkat kembali ke tanah Jawa untuk kedua kalinya (Yusuf, 2003: 42-43).

Kunjungannya ke tanah Jawa dalam waktu relatif singkat tersebut, kurang lebih satu tahun, telah memberikan "semangat baru" dalam mempelajari Islam. Ia memulai pengembaraannya dari kota Yogyakarta, kota tempat Muhammadiyah — sebagai organisasi pembaru Islam - itu lahir. Melalui pamannya (Ja'far Amrullah), ia kemudian memperoleh kesempatan untuk mengikuti kursus-kursus yang diadakan oleh Muhammadiyah dan Syarikat Islam. Pada kesempatan inilah Hamka dapat berjumpa dengan $\mathrm{Ki}$ Bagus Hadikusumo, dan dari dialah Hamka memperoleh pelajaran tafsir Alquran. Di samping itu, ia bertemu dengan HOS Cokroaminoto, dan mendengar ceramahnya mengenai Islam dan Sosialisme. Selain itu, ia sempat juga bertukar pikiran dengan beberapa tokoh penting lainnya, seperti H. Fachruddin dan Syamsul Ridjal, yaitu tokoh Jong Islamieten Bond (JIB) (Yusuf, 2003:43).

Kesadaran baru dalam melihat Islam yang didapatkannya di Yogyakarta itulah yang kemudian memperoleh pengukuhannya pada saat ia berada di Pekalongan selama kurang lebih enam bulan. Dari menantu ayahnya, yaitu A. R. Sutan Mansur yang menetap di kota Pekalongan itu telah memberinya "jiwa perjuangan". Sejak saat itulah ia memastikan untuk mengaktualisasikan dirinya sebagai seorang pengajar dan penyiar Islam. Di usia yang relatif sangat muda, yakni 16 tahun, ia telah berpidato di mana-mana dengan jiwa dan semangat kesadaran baru tersebut (Yusuf, 203:44-45).

Dengan modal intelektual dan semangat pergerakan yang dimilikinya seperti tergambar di atas itulah kemudian Hamka kembali ke Minangkabau. Mulai saat itu ia menapaki jalan yang dipilihnya sebagai seorang tokoh dan ulama dalam arus perkembangan pemikiran 
dan pergerakan di Indonesia. Di usia 17 tahun, ketika kembali ke Minangkabau dari perjalanannya di tanah Jawa tersebut, ia telah tumbuh menjadi pemimpin di tengah-tengah lingkungannya. Ia mulai berpidato dan bertablig di tengah-tengah masyarakat Minang yang telah melahirkan dan membesarkannya. Ia membuka kursus pidato bagi teman-teman sebayanya di Surau Jembatan Besi. Kepiawaiannya dalam menyusun kata-kata saat berpidato dan menulis telah menempatkannya pada posisi istimewa di antara teman-temannya. Ia berupaya mencatat dan menyusun kembali pidato teman-temannya lalu diterbitkan dalam sebuah majalah yang dipimpin dan diberinya nama Khatibul Ummah (Yusuf, 2003:45-46; Depag RI, 1993, I: 344).

Tahun 1930, Hamka mengikuti Kongres Muhammadiyah ke-19 di Bikittinggi, dan ia tampil sebagai pemberi saran dengan membawakan sebuah makalah yang berjudul, Agama Islam dan Adat Minangkabau. Kemudian ketika Muktamar Muhammadiyah ke 20 di Yogyakarta pada tahun 1931, ia tampil lagi dengan ceramah berjudul, Muhammadiyah di Sumatera. Setahun kemudian (1932), atas kepercayaan Pimpinan Pusat Muhammadiyah, ia diutus ke Makassar sebagai muballig. Tahun 1933, ia menghadiri Muktamar Muhammadiyah di Semarang. Dan pada tahun 1934, ia diangkat menjadi anggota tetap Majelis Konsul Muhammadiyah Sumatera Tengah. Selanjutnya, setelah kembali dari Makassar, ia mendirikan Kulliyatul Muballighin (Sekolah) di Padang Panjang. Tahun 1936, ia pindah ke Medan. Di kota inilah, ia bersama dengan M. Yunan Nasution menerbitkan majalah Pedoman Masyarakat, majalah yang menurut M. Yunan Nasution, telah memberikan andil yang begitu besar pada kepengarangan dan kepujanggaan Hamka di masa depan. Dengan demikian terbitlah karya-karyanya, seperti Di Bawah Lindungan Ka'bah, Pedoman Muballig Islam, Tenggelamnya Kapal van Der Wijk, Tasawuf Modern, Falsafah Hidup, Merantau ke Deli dan Tuan Direktur (Yusuf, 2003:48-49; Mengenai karya-karyanya, Bandingkan Tim IAIN Syahid, 1992:294).

Pada tahun 1942, Jepang mendarat di kota Medan, kehadirannya telah membawa perubahan yang bersifat negatif, seperti bendera Merah Putih tidak bisa dinaikkan lagi, segala bentuk persyarikatan dan perkumpualan dilarang, dan seluruh rakyat harus turut serta dalam membantu cita-cita untuk memenangkan Perang Asia Timur Raya. Karena keadaan yang demikian itu, maka hampir seluruh masyarakat 
kecewa. Sementara Hamka sendiri mendapatkan posisi yang istimewa dari Pemerintah Jepang. Sebagai tokoh Muhammadiyah dan pemuka masyarakat, pada tahun 1944 Hamka diangkat sebagai anggota Syu Sangi Kai (Dewan Perwakilan Rakyat). Dalam posisinya yang demikian, ia diminta oleh pemerintah Jepang untuk mengatasi berbagai problem yang muncul di kalangan umat Islam. Kedudukan tersebut telah memposisikannya sebagai "anak emas" Jepang, sehingga menjadikannya tersisih di kalangan masyarakat Medan, bahkan di organisasinya, Muhammadiyah. Kritik dan sumpah serapah memberondongnya, sehingga menjadikan ia menggunakan istilahnya sendiri "lari malam" dari kota Medan (Yusuf, 2003:49).

Karena kondisi di atas, maka pada tahun 1945 Hamka meninggalkan kota Medan menuju Padang Panjang. Kedatangannnya itu disambut gembira sahabat-sahabatnya, dan ia diserahi kembali untuk memimpin Kulliyatul Muballighin (Sekolah). Perhatian yang terfokus pada pengelolaan sekolah tersebut menjadikan ia memiliki kesempatan untuk menulis kembali. Pada masa inilah terbit bukubukunya seperti, Negara Islam, Islam dan Demokrasi, Revolusi Pikiran, Revolusi Agama, Adat Minangkabau Menghadapi Revolusi dan Dari Lembah Cita-Cita. Kemudian pada tahun 1946, ketika Konferensi Muhammadiyah diselenggarakan di Padang Panjang, ia terpilih sebagai Ketua Muhammadiyah. Pada tanggal 18 Desember 1949, ia memutuskan untuk pindah dari Minangkabau menuju ibu kota Jakarta. Pada tahun 1955, ketika pemilihan umum berlangsung di Indonesia, ia terpilih sebagai anggota Konstituante dari partai Masyumi (Yusuf, 2003:49-51).

Selain hal di atas, Hamka pun pernah menjadi pejabat tinggi dan penasihat Departemen Agama. Tahun 1952, Pemerintah Amerika Serikat mengundangnya untuk menetap selama empat bulan di Amerika Serikat. Sejak kunjungan tersebut, Hamka memiliki pandangan yang lebih inklusif terhadap negara-negara non-Muslim. Sepulangnya dari Amerika, ia menerbitkan buku berjudul, Empat Bulan di Amerika sebanyak dua jilid. Setelah itu, secara berturut-turut ia menjadi anggota kebudayaan di Muangthai (1953), mewakili Departemen Agama menghadiri meninggalnya Budha ke-2500 di Burma, Konferensi Islam di Lahore Pakistan (1958), dan undangan Universitas Al-Azhar di Kairo, memberikan ceramah mengenai "Pengaruh Muhammad Abduh di Indonesia." Ceramah itu membuat 
Hamka memperoleh gelar Doktor Honorius Causa (Yusuf, 2003:52; Untuk proses pemberian gelar Doktor Honorius Causa, Lihat Hamka, 2005, I: 57-63). Di samping itu, ia pernah mengikuti konferensi Negara-negara Islam di Rabat 1968), Muktamar Mesjid di Mekah (1976), Seminar mengenai Isa dan Peradaban di Kuala Lumpur, Peringatan Seratus Tahun Muhammad Iqbal di Lahore, dan Konfrensi Ulama di Kairo (1977) (Yusuf, 2003:53).

Akhirnya, dua bulan sebelum wafat, Ia mengundurkan diri dari jabatan Ketua Umum MUI, karena masalah perayaan "natal bersama" antara umat Kristen dan penganut agama Islam. MUI yang diketuainya itu mengeluarkan fatwa bahwa seorang muslim yang mengikuti perayaan natal hukumnya haram. Kemudian dua bulan sesudah pengunduran dirinya, ia masuk rumah sakit karena serangan jantung yang cukup berat. Selama kurang lebih satu minggu, ia terbaring di Rumah Sakit Pertamina Jakarta, yang ditangani oleh para dokter ahli. Tanggal 24 Juli 1981 ia berpulang ke Rahmatullah dalam usia 73 tahun, dengan didampingi oleh isterinya Khadijah, dan puteranya Afif Amrullah serta beberapa teman dekatnya (Yusuf, 2003: 54-55).

\section{Tentang Tafsir Al-Azhar}

Penamaan Tafsir al-Azhar tidak terlepas dari penamaan "Masjid Agung Kebayoran Baru" dengan "Masjid Agung Al-Azhar" oleh Rektor Universitas al-Azhar, Syaikh Mahmoud Syaltout pada thn 1960 (Hamka, 2005, I: 64) Kuliah Subuh yang disampaikan oleh Hamka di Mesjid Agung Al-Azhar, mulai tahun 1959. Pada saat itu mesjid tersebut belum bernama Al-Azhar. Pada waktu yang bersamaan, Hamka bersama dengan K.H. Fakih Usman dan H.M. Yusuf Ahmad menerbitkan sebuah majalah yang bernama Panji Masyarakat (Yusuf, 2003:55).

Adapun yang memotivasi Hamka dalam menulis tafsir Al-Azhar adalah (1) ia melihat bahwa mufasir-mufasir klasik sangat gigih atau ta'assub (fanatik) terhadap mazhab yang mereka anut, bahkan ada di antara mereka yang sekalipun redaksi suatu ayat nyata-nyata lebih dekat kepada satu mazhab tertentu, akan tetapi ia tetap menggiring pemahaman ayat tersebut kepada mazhab yang ia anut; (2) adanya suasana baru di negara (Indonesia) yang penduduknya mayoritas muslim, dan mereka haus akan bimbingan agama serta haus untuk 
mengetahui rahasia Alquran (Hamka, 2005, I:53-54); (3) ingin meninggalkan sebuah pusaka yang semoga mempunyai harga untuk ditinggalkan bagi bangsa dan umat Muslim Indonesia dan (4) hendak memenuhi sebaik-baiknya Husn al-Dzan (Baik sangka) Al-Azhar dan hutang budi yang mendalam padanya, yang telah memberinya penghargaan yang begitu tinggi (Gelar Doktor Honoris Causa) (Hamka, 2005, I:65).

Kemudian, ketika izin terbit Panji Masyarakat dicabut, caci dan fitnah kaum Komunis terhadap kegiatan Hamka di Masjid Al- Azhar semakin meningkat. Beruntunglah Jenderal Sudirman dan Kolonel Mukhlas Rowi, diupayakanlah penerbitan majalah Gema Islam. Pimpinan formal Gema Islam adalah $\mathrm{J} S$ dan $\mathrm{K}$ M S, sedangkan pimpinan aktifnya adalah Hamka. Ceramah-ceramah Hamka seusai shalat Shubuh di Masjid Al-Azhar yang membahas tafsir Alquran, secara teratur dimuat dalam majalah tersebut, dan hal itu berlangsung hingga Januari 1964 (Yusuf, 2003:56).

Pada hari Senin, 27 Januari 1964 bertepatan dengan tanggal 12 Ramadan 1383, setelah Hamka memberikan pengajian di depan kurang lebih 100 orang kaum ibu di Masjid Al-Azhar, ia ditangkap oleh penguasa Orde Lama, kemudian dimasukkan ke dalam tahanan. Sebagai tahanan politik, ia ditempatkan pada beberapa rumah peristirahatan di daerah puncak, yaitu Bungalow Herlina, Harjuna, Mess Brimob Megamendung dan Kamar Tahanan Polisi Cimacan. Di rumah tahanan tersebutlah, ia memiliki kesempatan yang memadai untuk menulis Tafsir Al-Azhar. Namun demikian, ketika kesehatannya mulai menurun, ia dipindahkan ke Rumah Sakit Persahabatan, Rawamangun Jakarta. Selama di rumah sakit tersebut, ia meneruskan penulisan tafsirnya, Tafsir Al-Azhar (Yusuf, 2003:56; Hamka, 2005, I: 56; Federspiel, 1996:56).

Setelah kejatuhan Orde Lama dan bangkitnya Orde Baru di bawah pimpinan Soeharto, dan kekuatan PKI pun telah ditumpas, saat itulah ia dibebaskan dari tuduhan. Pada tanggal 21 Januari 1966, ia menemukan kembali kebebasannya setelah mendekam dalam tahanan selama kurang lebih dua tahun, dengan tahanan rumah dua bulan dan tahanan kota dua bulan (Total 2 tahun 4 bulan). Kesempatan ini kemudian ia gunakan lagi untuk memperbaiki dan menyempurnakan Tafsir Al- Azhar yang telah ia tulis di berbagai rumah tahanan sebelumnya (Yusuf, 2003: 56-57). 
Penerbitan dan cetakan Tafsir Al-Azhar untuk pertama kalinya dilakukan oleh Penerbit Pembimbing Masa, pimpinan H. Mahmud. Yaitu menyelesaikan penerbitan dari juz 1 sampai juz ke-4. Lalu diterbitkan juga juz 15 sampai dengan juz 30 oleh Pustaka Islam Surabaya. Akhirnya Yayasan Nurul Islam Jakarta menerbitkan juz 5 sampai dengan juz 14 (Yusuf, 2003: 57).

\section{METODOLOGI TAFSIR AL-AZHAR}

\section{Bentuk Penafsiran}

Jika diperhatikan penafsiran Hamka dalam kitab tafsirnya, Tafsir Al-Azhar, ditinjau dari segi sumber atau bentuk/manhaj tafsir, maka ia merupakan perpaduan antara tafsir bi al-Ma'tsur dan bi alRa'yi. Hal ini tampak misalnya ketika ia menafsirkan Q.S Al- Baqarah [2]:158:

$$
\text { إن الصفا و المروة من شعائر الله }
$$

Terjemahnya

Sesungguhnya Shafa dan Marwah itu adalah dari pada syiarsyiar Allah jua.

Menurut Syaikh Muhammad Abduh ayat ini masih urutan dari masalah peralihan kiblat, meskipun pada tafsir-tafsir yang lain seakanakan telah terpisah. Menyebutkan dari hal Sa'i di antara Shafa dan Marwah setelah memperingatkan menyuruh sabar dan salat, guna menerima segala penyempurnaan nikmat Tuhan kelak, dan supaya tahan menderita segala macam percobaan, maka dengan ayat ini dibayangkanlah pengharapan, bahwa akan datang masanya mereka akan berkeliling di antara bukit Shafa dan Marwah. Betapapun besarnya kesulitan yang tengah dihadapi, namun pengharapan mesti selalu dibayangkan. Apatah lagi kalau yang membayangkan pengharapan Allah Ta'ala sendiri (Hamka, 2005, II:35). Selanjutnya ia menjelaskan:

Bahasa kita Indonesia telah kita perkaya juga dengan memakai kalimat syi'ar. Kita telah selalu menyebut syiar Islam. Syiar artinya tanda. Kata jamaknya adalah sya' air. Sya'airallah artinya tanda-tanda peribadatan kepada Allah. Ketika mengerjakan haji banyaklah terdapat syiar itu. Unta-unta dan lembu yang akan dikurbankan waktu habis haji dilukai tengkuknya, sebagai tanda. Melukai itupun dinamakan syiar. Shalat di makam Ibrahim adalah termasuk syiar ibadat.. Tawaf keliling Ka'bah' 
wuquf di Arafah dan di ayat ini disebut berjalan atau Sa'i di antara Shafa dan Marwah itupun satu di antara syiar-syiar (Sya'air) itu pula, dan melempar jamrah di Mina. Syiar-syiar demikianlah adalah termasuk ta'abbudi, sebagai imbangan dari ta'aqquli. Ta'abbudi artinya ialah ibadat yang tidak dapat dikorek-korek dengan akal mengapa dikerjakan demikian. Ta'aqquli ialah yang bisa diketahui dengan akal. Kita mengetahui apa hikmahnya mengerjakan shalat, itu namanya ta'aqquli. Teatapi kita tak dapat mengakali mengapa zuhur empat rakaat dan subuh dua rakaat. Itu namanya ta'abbudi (Hamka, 2005, II: 35-36).

Lebih lanjut ia mengemukakan:

Menurut Hadits Bukhari dan Muslim dari Ibn Abbas, syiar sa'i adalah kenangan terhadap Hajar (Isteri muda Ibrahim) seketika Ismail dikandungnya telah lahir, sedang dia ditinggalkan di tempat itu oleh Ibrahim seorang diri, sebab Ibrahim melanjutkan perjalanannya ke Syam, maka habislah air persediaannya dan nyaris keringlah air susunya, sedang sumur untuk mengambil air tidak ada di tempat itu. Anaknya Ismail telah menangis-nangis kelaparan, hingga hampir parau suaranya. Maka dengan harap-harap cemas, setengah berlarilah (Sa'i) Hajar itu di antara kedua bukit ini mencari air, sampai 7 kali pergi dan balik. Anaknya tinggal dalam kemahnya seorang diri di lembah bawah. Tiba-tiba kedengaran olehnya suara dan kelihatan burung terbang. Padahal tangis anaknya kedengaran pula meminta susu. Selesai pulang balik 7 kali itu diapun berlarilah kembali ke tempat anaknya yang ditinggalkannnya itu.Dilihatnya seorang Malaikat telah menggali-gali tanah di ujung kaki anaknya, maka keluarlah air. Dengan cemas dipeluklah air itu seraya berkata: Zam! Zam! Yang artinya, berkumpullah, berkumpullah (Hamka, 2005, II:36-37; al- Bukhârî, 1993, II: 206, Hadis ke 1643)!

Penafsiran Hamka terhadap Q.S Al- Baqarah (2):158 di atas jelas mengindikasikan perpaduan tafsir bi al-ra'y dan bi al-ma'thûr, di mana ia memulai penafsirannya dengan menjelaskan munâsabah ayat dengan mengutip Muhammad Abduh. Kemudian menjelaskan kosa kata ayat sya'air secara rasional. Setelah itu, ia menjelaskannya dengan hadis Rasulullah saw. Akan tetapi, karena penafsiranpenafsirannya yang lebih dominan dalam tafsirnya adalah ra'yi-nya 'pemikirannya', maka itulah kemudian Baidan mengklasifikasikan Tafsir al- Azhar sebagai tafsir yang menggunakan bentuk $\mathrm{ra}^{\prime} y$ 'pemikiran' (Baidan, 2003:106).

Apa yang dikemukakan Hamka di atas yang menyatakan bahwa $s a^{\prime} i$, kurban dan melempar jamrah adalah syiar-syiar Allah yang sifatnya ta'abbudi, hemat penulis tidak sepenuhnya ta'abbudi lagi. 
karena $s a^{\prime} i$ sebagaimana hadis yang dikemukakan oleh Hamka sendiri adalah sebagai kenangan dan mencontohi Siti Hajar (Isteri Nabi Ibrahim) yang dilakukannya sebanyak 7 kali bolak-balik antara Shafa dan Marwah, pada saat ia kehabisan air, dan sebanyak itulah batas kemampuannya. Sedangkan kurban adalah untuk mengikuti apa yang dilakukan oleh Nabi Ibrahim terhadap anaknya Ismail, lalu Allah menggantinya dengan kibasy. Hal itu sebagai tanda ketaatan kepada Allah. Sementara melontar jamrah adalah juga untuk mengikuti Ibrahim, di mana ketika akan menyembelih Ismail, ia dihalang-halangi oleh syaitan, lalu ia melemparnya. Itulah yang dicontohi oleh para jemaah haji dengan melontar jamrah sebagai lambang permusuhan terhadap syaitan.

\section{Metode Penafsiran}

Mencermati penafsiran Hamka dalam tafsirnya itu, yang mengikuti urutan ayat-ayat dalam Alquran dan menjelaskannya secara analitis, maka jelas ia menggunakan metode tahlîlî karena metode tahlîlî yang dalam istilah Baqir al- Shadr, metode tajzi'i - sebagai yang dikutip Shihab, (1992:86) - adalah metode yang mufasirnya berupaya untuk menjelaskan kandungan ayat-ayat Alquran dari berbagai sisi dengan memperhatikan urutan ayat-ayat Alquran sebagaimana yang termaktub dalam mushaf.

Hal tersebut tampak jelas pada penafsirannya terhadap Q.S AlTâriq [86]:11 sebagai berikut:

Terjemahnya:

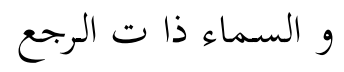

Demi langit yang menurunkan hujan

Demi langit yang menurunkan hujan. Langit yang dimaksud di sini tentulah yang di atas kita. Sedangkan di dalam mulut kita yang sebelah atas kita namai langit-langit, dan tabir sutera warna-warni yang dipasang di sebelah atas singgasana raja atau di atas pelaminan tempat mempelai dua sejoli bersanding dinamai langit-langit pula sebagai alamat bahwa kata-kata langit itu pun dipakai untuk yang di atas. Kadang-kadang diperlambangkan sebagai ketinggian dan kemuliaan dan kemuliaan Tuhan, lalu kita tadahkan tangan ke langit ketika berdoa. Maka dari langit itulah turunnya hujan. Langitlah yang menyimpan air dan menyediakannya lalu menurunkannya menurut 
jangka waktu. Kalau dia tidak turun kekeringanlah manusia di bumi ini dan matilah kita. Mengapa raj'i artinya di sini jadi hujan ? sebab hujan itu memang air dari bumi juga, mulanya menguap naik ke langit, jadi awan berkumpul dan turun kembali ke bumi, setelah menguap lagi naik kembali ke langit dan turun kembali ke bumi. Demikian terus-menerus. Naik kembali, turun kembali (Hamka, 2005, XXX:117).

Mengenai penafsiran Hamka tersebut di atas, Baidan (2003:106) berkomentar bahwa Hamka menggunakan metode analitis sehingga peluang untuk memaparkan tafsir yang rinci dan memadai menjadi lebih besar. Untuk menjelaskan kata "langit", ia mengkomparasikannya dengan langit-langit yang terdapat dalam rongga mulut dan langit-langit yang terdapat pada pelaminan, dan bahkan dengan langi-langit yang terdapat pada istana raja. Kemudian ia menjelaskan bahwa kata "langit" terkadang juga dilambangkan sebagai ketinggian dan kemuliaan Tuhan, di mana manusia ketika berdoa ia mengadahkan tangannya ke arah atas, langit. Ia juga menjelaskan mengapa kata raj'i pada ayat tersebut bermakna "hujan." Dengan demikian, jelas bahwa Tafsir Al-Azhar menggunakan metode tahîilî.

\section{Corak Tafsir}

Mengamati penafsiran-penafsiran Hamka dalam Tafsir AlAzhar-nya, ditinjau dari segi corak penafsiran, di mana ia senantiasa merespons kondisi sosial masyarakat dan mengatasi problem yang timbul di dalamnya, maka jelas ia memakai corak Adab ijtima'i (sosial kemasyarakatan). Sebab corak Adab ijtima'i sendiri -sebagai dikemukakan Shihab dalam (Yusuf, 2003:xxxiv adalah corak tafsir yang menerangkan petunjuk-petunjuk ayat Alquran yang berhubungan langsung dengan kehidupan amasyarakat dan berupaya untuk menanggulangi masalah-masalah mereka dengan mengedepankan petunjuk-petunjuknya.

Hal yang demikian misalnya dapat dilihat pada penafsirannya terhadap Q.S Al- Baqarah [2]:159 berikut ini:

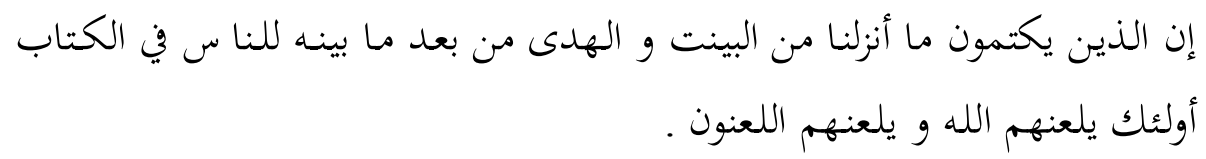


Terjemahnya:

Sesungguhnya orang-orang yang menyembunyikan apa yang telah pernah Kami turunkan dari keterangan-keterangan dan petunjuk, setelah Kami terangkan dianya kepada manusia di dalam Kitab, mereka itu akan dilaknat oleh Allah dan mereka pun akan dilaknat oleh orang-orang yang melaknat. Sesungguhnya orang-orang yang menyembunyikan apa yang telah pernah Kami turunkan, dari keterangan-keterangan dan petunjuk. .

Keterangan-keterangan itu ialah tentang sifat-sifat rasul akhir zaman yang akan diutus Tuhan, yaitu Nabi Muhammad saw. yang demikian jelas sifat-sifatnya itu diterangkan, sehingga mereka kenal sebagaimana mengenal anak mereka sendiri. Dengan menyebut keterangan-keterangan, jelaslah bahwa penjelasan ini bukan di satu tempat saja dan bukan satu kali saja, melainkan di berbagai kesempatan. Dan yang dimaksud dengan petunjuk atau hudan ialah intisari ajaran Nabi Musa, yang sama saja dengan intisari ajaran Muhammad saw. yaitu tidak mempersekutukan yang lain dengan Allah, tiada membuatnya patung dan berhala. Setelah Kami terangkan dianya kepada manusia di dalam Kitab. Artinya, segala keterangan dan petunjuk itu jelas tertulis di Kitab Taurat itu sendiri, dan sudah disampaikan kepada manusia, sehingga tidak dapat disembunyikan lagi. Mereka itu akan dilaknat oleh Allah dan mereka pun akan dilaknat oleh orang-orang yang melaknat (Ujung ayat 159). Orang yang menyembunyikan keterangan-keterangan itu adalah orang yang tidak jujur, orang-orang yang curang, yang telah melakukan korupsi atas kebenaran, karena mempertahankan golongan sendiri. Orang yang semacam ini pantaslah mendapat laknat Tuhan dan laknat manusia. Kecurangan terhadap ayat suci di dalam Kitab-kitab Tuhan, hanya semata-mata mempertahankan kedudukan, adalah satu kejahatan yang patut dilaknat (Hamka, 2005, II:40-41).

Penafsiran Hamka di atas menjelaskan kondisi masyarakat Yahudi yaitu umat Nabi Musa yang tidak percaya akan diutusnya Muhammad sebagai nabi pada akhir zaman, yaitu melakukan suatu kecurangan dan ketidakjujuran dengan menyembunyikan informasi tentang hal itu, yang nayata-nayata telah disebutkan dalam kitab mereka sendiri. Oleh karena itu, mereka sangat layak dilaknat oleh Allah dan manusia. Selanjutnya, Hamka menjelaskan sebagai berikut: 
Ayat yang tengah kita tafsirkan ini adalah celaan keras atas perbuatan curang terhadap kebenaran. Sebab itu janganlah kita hanya menjuruskan perhatian kepada sebab turunnya ayat, yaitu pendeta Yahudi dan Nasrani tetapi menjadi peringatan juga kepada kita umat Muslimin sendiri. Apabila orang-orang yang dianggap ahli tentang agama, tentang Alquran dan Hadits telah pula menyembunyikan kebenaran, misalnya karena segan kepada orang yang berkuasa, atau takut pengaruh akan hilang terhadap pengikut-pengikut mereka, maka kutuk yang terkandung dalam ayat ini pun akan menimpa mereka. Terutama dari hal Amar Ma'ruf, Nahi Munkar, menganjur-anjurkan berbuat yang baik-baik dan mencegah daripada mungkar, menjadi kewajibanlah bagi orang-orang yang telah dianggap ahli dalam hal agama. Apatah lagi karena sabda Nabi :

العلماء و رثـة الأنبياء (رواه ابو داود والترمذي وابن ماجه وابن حبان

$$
\text { و البيهقي من حديث أبي الدرداء ) }
$$

Terjemahnya:

Ulama-ulama adalah penjawat waris Nabi-Nabi.

(Dirawikan oleh Abu Daud, Turmudzi, Ibnu Majah, Ibnu Hibban, AlBaihaqi dari Hadits Abu Darda).

Lantaran itu dalam Islam ulama mempunyai dua kewajiban, yaitu menuntut ilmu agama untuk mengajarkannya pula kepada orang yang belum tahu, sehingga diwajibkan bagi yang belum tahu itu bertanya kepada yang tahu. Kewajiban yang kedua menyampaikan atau mentablighkan. Ulama dalam Islam bukanlah hendaknya sebagai sarjana ayang duduk di atas istana gading, menjauhkan diri dari bawah dan melihat-lihat saja dari atas. Lantaran itu maju mundurnya agama di suatu negeri amat bergantung kepada aktif tidaknya ulama di tempat itu dalam menghadapi masyarakat. Kalau mereka telah menyembunyikan pula ilmu dan pengetahuan, keterangan-keterangan dan petunjuk, kutuk dan laknat Tuhanlah yang akan menimpa dirinya. Dan manusia pun mengutuk pulalah, sehingga kadang-kadang jika terdapat banyak di satu negeri, , maka bertanyalah orang. "Tidakkah ada ulama di sini ?" (Hamka, 2005, II: 43-44).

Penafsiran Hamka terhadap ayat tersebut mengarah kepada pengecaman keras terhadap orang Yahudi dan Nasrani yang bersikap hipokrit, yaitu berpura-pura tidak tahu akan kerasulan Muhammad sehingga mereka menyembunyikan hal itu, padahal sebenarnnya hal tersebut telah tercantum dalam kitab mereka sendiri, yang boleh jadi hal itu mereka lakukan karena kekhawatiran akan hilangnya pengaruh mereka atau hal yang lain. Kemudian kondisi tersebut, Hamka arahkan 
kepada kaum muslimin, terlebih kepada orang yang ahli dalam bidang Alquran dan hadis (ulama), agar mereka tidak melakukan hal yang sama, yaitu menyembunyikan kebenaran. Akan tetapi, hendaklah ia bangkit atau berada di tengah-tengah masyarakat untuk memberikan arahan-arahan, pengajaran atau petunjuk-petunjuk kepada kebenaran supaya mereka tidak mendapat laknat dari Allah swt. dan manusia. Hal tersebut mengisyaratkan bahwa Tafsir Al- Azhar menggunakan corak Adab Ijtimâ' $\hat{\imath}$.

Dengan demikian, sangat tepat kalau kemudian Shihab menegaskan bahwa Tafsir Al- Azhar adalah salah satu tafsir yang memakai corak Adab Ijtimâ'i. Sekalipun corak ini melakukan penafsiran mengenai aneka macam persoalan yang berhubungan dengan kandungan ayat yang di tafsirkan seperti : filsafat, teologi, hukum, tasawuf dan sebagainya. Namun penafsiran itu tidak keluar dari coraknya yang berupaya mengatasi problem-problem masyarakat, dan memotivasinya untuk memperoleh kemajuan duniawi dan ukhrawi menurut petunjuk-petunjuk Alquran (Shihab dalam Yusuf, 2003: xxxiv; Baidan, 2003:105-106).

Berdasarkan penafsiran-penafsiran Hamka di atas, dapat dikemukakan bahwa sistematika penafsiran dalam Tafsir Al-Azhar adalah sebagai berikut: (1) ayat, (2) terjemahan (3) munâsabah, (4) tafsir ayat / kosa kata, (5) asbâb al-nuzûl dan (6) kandungan ayat/ kesimpulan.

Sebelum menulis ayat dan terjemahannya, ia mencantumkan terlebih dahulu nama surat dan terjemahannya, urutan surat dan jumlah ayatnya tempat turunnya. Kemudian ia menulis ayat dan terjemahannya. Kelompok ayat yang ditampilkannya biasa terdiri atas beberapa ayat, seperti $7,6,5,4,3$ atau 2 ayat dengan disertai terjemahannya masing-masing. Kemudian ia memberi pendahuluan yang isinya menjelaskan sebab penamaan surat tersebut, menyebutkan jumlah ayatnya lagi, menjelaskan sedikit sejarah yang mengantar cakupan pembahasan surat itu, dan inti sarinya. Sebelum mengemukakan munâsabah ayat, ia terlebih dahulu memberi judul pembahasan yang akan disorot dalam ayat tersebut, namun terkadang ia juga tidak memberinya. Setelah itu ia mengemukakan munâsabah ayat (Tampaknya pada awal surat Al-Baqarah itu ia tidak menjelaskan munâsabah-nya), kemudian mencantumkan terjemahan ayat yang akan ditafsirkan, lalu diikuti dengan penjelasan, ayat yaitu dengan 
menjelaskan kosakata yang penting dalam ayat tersebut. Selanjutnya ia menjelaskan asbâb al-nuzûl ayat itu bila ada, dengan mengemukakan hadis untuk memperkuat penafsirannya. Kemudian ia menjelaskan kandungan atau kesimpulan ayat tersebut, meskipun tidak selamanya ia lakukan hal itu.

Melihat lebih jauh penafsiran Hamka dalam Tafsir Al-Azhar, tampaknya ada yang spesifik dan sekaligus menjadi karakteristik penafsirannya dibanding mufasir-mufasir yang lain, yaitu ketika ayat yang ditafsirkannya itu relevan dengan apa yang pernah ia alami dalam kehidupan maka pengalaman yang ia alami sendiri itu dikemukakannya dalam rangka memperkuat penafsirannya.

\section{PENUTUP}

Mencermati apa yang telah dipaparkan di atas maka dapat disimpulkan bahwa Tafsir Al- Azhar adalah Tafsir yang disusun oleh seorang yang bernama Prof. Dr Hamka yang mulai ditulis sejak tahun 1959, lalu disampaikan dalam bentuk kuliah Subuh di Masjid AlAzhar dan diselesaikannya (Ditulis) dipenjara -dengan penuh kesabaran, ketabahan dan mujahadah pantang menyerah- dari 27 Januari 1964 (Hari masuknya di penjara) hingga 21 Januari 1966 (Hari keluarnya dari penjara), yakni dari akhir orde lama hingga awal orde baru, kurang lebih 6 tahun, yang berjumlah 30 jilid. Tafsir ini disusun dengan menggunakan Manhaj al-Ra'y, Metode Tahlîlî, Laun Adab alIjtimâ'i dan Mazhab Salaf dan Qadariyah.

\section{DAFTAR PUSTAKA}

Baidan, Nashruddin. 2003. Perkembangan Tafsir Al- Qur'an di Indonesia, Cet. I. Solo: Penerbit PT. Tiga Serangkai.

Bakar, Osman. 2003. Islam dan Dialog Peradaban. Terjemahan oleh Imam Khoiri dan Oman Fathurrohman SW dari Islam and Civilizational Dialogue: The Quest for a Truly Universal Civilization. Cet. I. Yogyakarta: Fajar Pustaka Baru.

al-Bukhârî, Abû 'Abd Allâh Muh $\square$ ammad bin Ismâ'îl bin Ibrâhîm1414 H/1994 M. $S \square$ ahîh al-Bukhârî. Juz. II. t.tp: Dâr al- Fikr.

Dahlan, Abdul Aziz. 2001. Takdir dalam Kajian Empat Tokoh Muhammadiyah. Cet. I. Padang: IAIN-IB Press.

Departemen Agama RI. 1993. Eensiklopedi Islam di Indonesia. Juz. I. Jakarta: Departemen Agama RI.

Federspiel, Howard M. 1417 H/1996 M. Kajian Al- Quran di Indonesia: Dari Mahmud Yunus hingga Quraish Shihab. Terjemahan oleh Tajul 
Arifin dari Popular Indonesian Literature of Quran. Cet. I. Bandung: Penerbit Mizan.

Hamka. 2005. Tafsir Al- Azhar. Juz. I, II, VIII, XXVI, Jakarta: Penerbit Pustaka Panjimas.

Shihab, M. Quraish. 1412 H /1992 M. Membumikan Al-Quran: Fungsi dan Peran Wahyu dalam Kehidupan Masyarakat Cet. I. Bandung: Penerbit Mizan.

."Kata Pengantar" dalam Yunan Yusuf. 1424 H / 2003 H. Corak Pemikiran Kalam Tafsir Al-Azhar: Sebuah Telaah atas Pemikiran Hamka dalam Teologi Islam. Cet. II. Jakarta: Penerbit Penamadani.

Asy-Syirbashiy, Ahmad. 1994. Sejarah Tafsir Quran, Terjemahan oleh Pustaka Firdaus. Cet. III. t.tp.: Pustaka Firdaus.

Tim Penulis IAIN Syarif Hidayatullah. 1992. Ensiklopedi Islam Indonesia. Jakarta: Penerbit Djambatan.

Yusuf, Yunan. 1424 H / 2003 M. Corak Pemikiran Kalam Tafsir Al- Azhar: Sebuah Telaah atas Pemikiran Hamka dalam Teologi Islam. Cet. II. Jakarta: Penerbit Penamadani. 